\title{
COMING OUT SEBAGAI STRATEGI PRESENTASI PEKERJA MINORITAS SEKSUAL MELAWAN DISKRIMINASI MENURUT ONTOLOGI MATEMATIKA ALAIN BADIOU
}

\section{Muhammad Irfan Syaebani dan Embun Kenyowati Ekosiwi}

Dept. of Philosophy, Faculty of Humanities, Universitas Indonesia

Email: irfan.syaebani@gmail.com; embunjf@yahoo.co.id

Abstrak

Pekerja minoritas seksual sering memilih untuk menyembunyikan identitas seksualnya disebabkan ketakutan akan perlakuan diskriminatif. Hal ini berujung pada posisi mereka yang tidak tampak dalam presentasi para pekerja. Akibatnya terjadi hubungan yang eksklusif antara pekerja mayoritas seksual heteronormatif dengan pekerja minoritas seksual non-heteronormatif karena tiadanya interaksi yang intens dan personal. Hal ini menjadikan pekerja minoritas seksual menjadi bagian yang tersisih dalam presentasi para pekerja dan justru melanggengkan diskriminasi berdasarkan seksualitas. Melalui teori matematika sebagai ontologi yang digagas Alain Badiou, tulisan ini menggagas strategi pekerja minoritas seksual untuk menjadi tampak dalam presentasi pekerja melalui coming out sebagai suatu peristiwa.Coming out pun pada akhirnya dapat menjadi strategi untuk mengakhiri diskriminasi pekerja yang didasarkan pada seksualitas.

Kata kunci: seksualitas, pekerja minoritas seksual, coming out, Alain Badiou, matematika, ontologi.

\section{Abstract}

Sexual minority workers often choose to hide their true sexual identity to avoid discriminative action towards them. This leads to their invisible position in the workers presentation. Hiding true sexual identity of sexual minority workers creates exclusive relationship between heteronormative majority workers and non-heteronormative minority workers because of unavailability of intensive and personal interactions between them. Thus it makes sexual minority workers are excluded from the workers presentation and preserving discrimination based on sexuality. Using mathematical theory formulated by Alain Badiou, this writing tries to propose a strategy for sexual minority workers to be visible in the workers presentation through 
coming out action as an event. Coming out in the end is a strategy to fight for equality and an action for discrimination based on sexuality to end.

Keywords: sexuality, sexual minority workers, coming out, Alain Badiou, mathematics, ontology.

\section{PENDAHULUAN}

Situasi ketenagakerjaan adalah suatu wilayah di mana Ada (being) hadir di dalam relasi antara pemberi kerja (employer) dan pekerja (employee). Dalam situasi ketenagakerjaan pekerja hadir melalui proses penghitungan sebagai satu satuan yaitu pekerja diperlakukan sebagai komponen pembentuk jumlah dalam bilangan 1, 2, 3, 4, dan seterusnya. Situasi ketenagakerjaan kemudian tidak lain dari efek terhadap penghitungan kehadiran (presentasi) dari para pekerja dalam suatu relasi tersebut. Pekerja diperlakukan sebagai satuan yang dapat dihitung jumlah keseluruhannya. Misalnya suatu perusahaan memiliki 12 pekerja didasarkan pada penghitungan satuan dari setiap pekerja yang hadir di perusahaan tersebut.

Situasi ketenagakerjaan di Indonesia masih dipenuhi oleh diskriminasi dan ketidakadilan terhadap pekerja terutama berdasarkan seksualitasnya. Padahal di dalam Undang-undang nomor 13 tahun 2003 telah diatur pasal mengenai antidiskriminasi, yaitu pada pasal 5 dan pasal 6 yang berbunyi, Pasal 5: Setiap tenaga kerja memiliki kesempatan yang sama tanpa diskriminasi untuk memperoleh pekerjaan. Pasal 6: Setiap pekerja/buruh berhak memperoleh perlakuan yang sama tanpa diskriminasi dari pengusaha.

Akan tetapi, pasal antidiskriminasi tersebut ternyata merupakan pasal yang setengah hati. Di dalam bagian penjelasan, pasal antidiskriminasi tersebut hanya ditujukan bagi diskriminasi yang didasarkan pada jenis kelamin, suku, agama, ras, warna kulit, aliran politik, dan penyandang cacat (kaum difabel). Pasal tersebut luput menyatakan penolakan terhadap diskriminasi yang didasarkan pada seksualitas. Pekerja yang memiliki seksualitas yang non-heteronormatif atau minoritas seksual tidak dianggap sebagai pekerja yang harus dilindungi dari praktik diskriminasi di tempat 
kerja. Akibatnya sering terjadi pekerja yang memiliki variasi seksualitas non-heteronormatif mengalami ketertindasan.

Infografis yang disusun oleh CNN Indonesia pada tanggal 2 Mei 2015 dalam rangka peringatan hari buruh Internasional menyebutkan bahwa kelompok seksualitas non-heteronormatif sering mengalami berbagai macam bentuk diskriminasi seperti: (1) dari $100 \%$ responden sebanyak $79,1 \%$ pernah mengalami kekerasan psikis (2) dari 100\% responden sebanyak $46,3 \%$ pernah mengalami kekerasan fisik (3) dari 100\% responden sebanyak 45,1\% pernah mengalami kekerasan seksual (4) dari 100\% responden sebanyak $26,3 \%$ pernah mengalami kekerasan ekonomi, dan (6) dari 100\% responden sebanyak 63,3\% pernah mengalami kekerasan budaya (Fajrian, 2015: 1). Kekerasan ini pun dialami oleh mereka yang berstatus sebagai pekerja. Kelompok waria (wanita-pria, identitas transgender) dianggap yang paling rentan terhadap diskriminasi, bahkan akses mereka terhadap pekerjaan pun sudah dibatasi. Negara pun kemudian seperti tutup mata terhadap fenomena ini. Dede Oetomo (2015:1) seorang aktivis hak asasi kelompok minoritas seksual menyatakan bahwa ketika waria yang mengalami diskriminasi ini melaporkan ke polisi, mereka malah mendapatkan diskriminasi dari polisi. Kalau ada waria melapor, tak jarang respons yang mereka terima dari polisi adalah ditertawakan.

Untuk menghindari diskriminasi dan ketidakadilan dalam perlakuan kerja, akhirnya banyak pekerja minoritas seksual lebih memilih untuk mencari aman dengan menyembunyikan identitasnya tersebut. Mereka lebih memilih untuk berpura-pura menjadi "normal" dalam artian berpura-pura mengikuti norma seksualitas yang heteronormatif dan menampilkan ekspresi gender sesuai dengan jenis kelaminnya. Perilaku berpura-pura inilah kemudian yang disebut sebagai bersembunyi di balik lemari (hiding in the closet). Dalam jangka pendek strategi ini merupakan strategi yang dianggap paling rasional dan memungkinkan untuk dilakukan dalam menghindari diskriminasi di tempat kerja. Akan tetapi, dalam 
jangka panjang strategi ini justru akan semakin memperparah diskriminasi dan bukan mengakhirinya.

Menurut Alain Badiou, situasi ketenagakerjaan adalah relasi presentasi dari para pekerja yang dihitung sebagai satu satuan. Badiou menggunakan teori himpunan dalam menjelaskan pemikirannya yang menyatakan bahwa sebagai suatu situasi, relasi ketenagakerjaan terdiri dari himpunan-himpunan para pekerja. Himpunan-himpunan ini (yang kemudian dihimpun dalam himpunan yang lebih besar lagi dan dihimpun lagi dalam himpunan yang lebih besar lagi) merupakan satuan pembentuk himpunan itu sendiri. Ini berarti elemen atau anggota atau penyusun dari suatu himpunan adalah selalu himpunan. Oleh sebab itu, bagi Badiou Ada atau Being selalu merupakan kejamakan, karena Ada atau Being tak lain adalah himpunan (Badiou, 2006: 52-59).

Akan tetapi, dalam teori himpunan anggota suatu himpunan bukan hanya anggota yang dihitung dalam satu satuan, tetapi juga ada anggota yang tidak dihitung sebagai satu satuan tapi juga merupakan bagian dari himpunan tersebut. Itu adalah himpunan kosong atau disimbolkan dengan \{\} atau $\emptyset$. Himpunan kosong ini dapat diidentifikasi dari proses penjabaran himpunan ke dalam bagian-bagiannya atau subsets. Di dalam himpunan bagian ini selalu terdapat himpunan kosong sebagai salah satu himpunan yang terdapat dalam situasi walau himpunan kosong ini bukan merupakan anggota atau elemen dari situasi (karena tidak terhitung) (Badiou, 2006: 60-69).

Kembali pada situasi ketenagakerjaan, apabila pekerja minoritas seksual memilih untuk menyembunyikan identitasnya maka mereka tidak akan terhitung dalam satu satuan di dalam himpunan pekerja walaupun secara laten mereka ada di dalam himpunan tersebut. Oleh karena tidak terhitung, presentasi atau kehadiran mereka adalah kehadiran laten dalam bentuk himpunan kosong. Akibatnya, presentasi pekerja minoritas seksual ini tetap tidak akan terhitung meskipun mereka ada secara inheren. Lebih 
lanjut, karena mereka tidak terhitung maka kondisi mereka akan tetap terpuruk karena kehadiran mereka menjadi tidak nampak.

Padahal di dalam konteks Indonesia, pekerja minoritas seksual bukan lagi sekedar mitos dan dongeng. Keberadaan mereka ditemukan walaupun masih dalam kondisi hiding in the closet. Menurut Boellstorff (2004: 159-161, bdk Boellstorff, 2005: 575) seorang antropolog yang melakukan penelitian di Indonesia menyatakan bahwa ribuan lelaki Indonesia mengidentifikasi dirinya sebagai gay dan kebanyakan dari mereka adalah termasuk ke dalam kelas pekerja. Keberadaan pekerja minoritas seksual di Indonesia ini tidak didukung oleh kondisi yang menguntungkan mereka. Seperti telah dibahas di awal, diskriminasi terhadap mereka begitu kental dan bahkan beberapa pihak mengingkari keberadaan mereka. Pekerja minoritas seksual di Indonesia dianggap sebagai mitos atau isu yang tidak perlu terlalu dirisaukan.

Tulisan ini berangkat dari perumusan masalah dengan menggunakan kerangka pemikiran Alain Badiou yang tertuang dalam bukunya Being and Event yang menggunakan pendekatan matematika. Matematika yang digunakan dalam hal ini adalah teori himpunan yang ditujukan untuk menjelaskan ontologi Ada. Teori yang digagas Alain Badiou ini diaplikasikan dan dikontekstualisasikan dalam proses perjuangan melawan diskriminasi pekerja minoritas seksual. Dari rumusan tersebut maka tercipta pernyataan tesis bahwa coming out adalah strategi presentasi pekerja minoritas seksual dalam melawan diskriminasi dalam dunia kerja.

Menggunakan bingkai teori Alain Badiou yang mengusung teori himpunan dalam menjelaskan ontologi filsafat, maka tulisan ini mencoba menawarkan strategi baru bagi pekerja minoritas seksual untuk melawan dan keluar dari perlakuan tidak adil yang mereka terima dalam situasi ketenagakerjaan mereka. Badiou yang menyatakan bahwa situasi ketenagakerjaan adalah sebuah kehadiran presentasi pekerja yang dihitung sebagai satu satuan memberikan harapan untuk menemukan jalan keluar dari problem diskriminasi 
melalui coming out yaitu perbuatan yang bukan menyembunyikan tetapi justru mengungkapkan jati diri mereka.

\section{SEKSUALITAS, MINORITAS SEKSUAL, PEKERJA MINORITAS SEKSUAL, DAN COMING OUT}

Menurut Utama (2013: 6) seksualitas adalah segala konsep yang meliputi jenis kelamin biologis, identitas dan peran gender, orientasi seksual, erotisisme, kenikmatan, kemesraan, dan reproduksi. Secara lebih jauh, dalam mendefinisikan seksualitas maka harus dipahami berbagai konteks atau dimensi yang melingkupinya yang dapat dibagi ke dalam empat konteks/dimensi besar yaitu; (1) dimensi biologis, (2) dimensi psikologis, (3) dimensi sosial, dan (4) dimensi budaya.

Di dalam dimensi biologis seksualitas terkait dengan organ reproduksi dan organ seksual, maka seksualitas dalam dimensi biologis terkait erat (terutama) dengan organ-organ genital dan alatalat reproduksi. Di sini seksualitas terkait dengan penis dan vagina, rahim, sperma, telur, dan fungsi-fungsi biologis lainnya yang mendukung proses reproduksi manusia. Dalam dimensi psikologis, seksualitas terkait dengan bagaimana seorang individu menghidupi dirinya dalam menjalankan perannya sebagai makhluk seksual. Di sini seksualitas kemudian terkait dengan aspek berpikir, emosi, dan perilaku. Oleh sebab itu, dalam aspek psikologis seksualitas umumnya terkait dengan konsep gender baik identitas gender maupun ekspresi gender. Dimensi berikutnya adalah dimensi sosial. Di dalam dimensi sosial, seksualitas dikaitkan dengan hubungan antarmanusia dan bagaimana pengaruh lingkungan kemudian membentuk hubungan tersebut. Misalnya di dalam dimensi sosial seksualitas terkait dengan konsep maskulinitas untuk manusia yang berjenis kelamin biologis laki-laki (memiliki penis) dan konsep feminin untuk manusia berjenis kelamin biologis perempuan (memiliki vagina). Atau misalnya konsep pernikahan adalah hubungan antara manusia berjenis kelamin berbeda. 
Sedangkan dimensi terakhir adalah dimensi budaya. Di dalam dimensi budaya, seksualitas merupakan bagian serta dipengaruhi oleh aspek-aspek lain di dalam masyarakat seperti aspek ekonomi, politik, agama, dan negara. Di sini seksualitas kemudian menjadi suatu konsep yang seolah-olah dapat diatur, diregulasi, dan dinormalisasi. Dalam dimensi budaya inilah kemudian seksualitas sering kali dianggap sebagai konsep yang bermasalah, karena definisi seksualitas kemudian menyempit dan sering kali dipandang dalam oposisi biner di mana satu posisi dianggap sebagai seksualitas yang sah dan normal sedangkan posisi yang lainnya dianggap sebagai seksualitas yang tidak sah dan tidak normal.

Seksualitas sering kali dianggap sebagai sesuatu yang tidak berubah, asosial, dan transhistoris (Alimi, 2004: 33). Penjelasan akan seksualitas yang dominan ini menganggap seksualitas sebagai bersumber pada hormon, psike, dan hukum Tuhan. Oleh karenanya, seksualitas adalah sesuatu yang ajeg dan merupakan kenyataan alamiah apa adanya dan menolaknya sebagai kenyataan yang sosial. Seksualitas adalah konstruk biologis yang didasarkan pada fungsi alamiah tubuh. Inilah kemudian yang disebut sebagai seksualitas yang alami, sah, dan normal. Seksualitas yang tidak mengikuti konstruk biologis ini kemudian disebut sebagai seksualitas yang menyimpang, tidak sah, dan tidak normal. Inilah yang disebut sebagai minoritas seksual. Konsep seksualitas yang biner ini (normal vs tidak normal), sejalan dengan logika ilmu pengetahuan yang bias. Menurut Muthmainnah (2008: 319), para feminis menganggap ilmu pengetahuan didominasi oleh androcentric sehingga membagi ilmu pengetahuan ke dalam kutub biner yang mengunggulkan laki-laki dan menepikan perempuan. Dalam seksualitas, maka posisi biner ini diterapkan pada pengunggulan seksualitas yang normal dan menepikan seksualitas yang dianggap tidak normal. Pengelompokkan seksualitas ke dalam posisi biner ini sudah banyak dikritik, seperti yang dilakukan pada feminis. Menurut Dania (2011: 152), gerakan feminis mempertanyakan asumsi dasar pemikiran biner dalam seksualitas, kontrol tubuh (terutama tubuh perempuan), 
serta esensialisme termasuk dalam hal esensialisme dalam seksualitas yang menganggapnya ajeg karena beresensi pada hormon, psike, dan hukum Tuhan. Relasi dalam gender dan seksualitas yang setara sebenarnya pun telah ditemukan dalam budaya Indonesia. Suku Baduy misalnya, menganggap bahwa hubungan antargender sebagai hubungan yang tidak saling mendominasi (Maharani, 2009: 211). Tidak ada posisi biner di mana yang satu lebih tinggi dan lain lebih rendah.

Penjelasan akan konsep seksualitas manusia yang rumit dan cair kemudian sering dilakukan oleh para aktivis dan akademisi dengan menggunakan suatu alat bantu sederhana yang disebut dengan genderbread person. Genderbread person memperlihatkan betapa seksualitas merupakan konsep yang luas dan cair serta tidak melulu bersifat biner yang saling beroposisi. Secara sederhana, seksualitas manusia dibagi ke dalam empat hal utama yaitu: (1) Identitas Gender, (2) Ekspresi Gender, (3) Orientasi Seksual, dan (4) Jenis Kelamin.

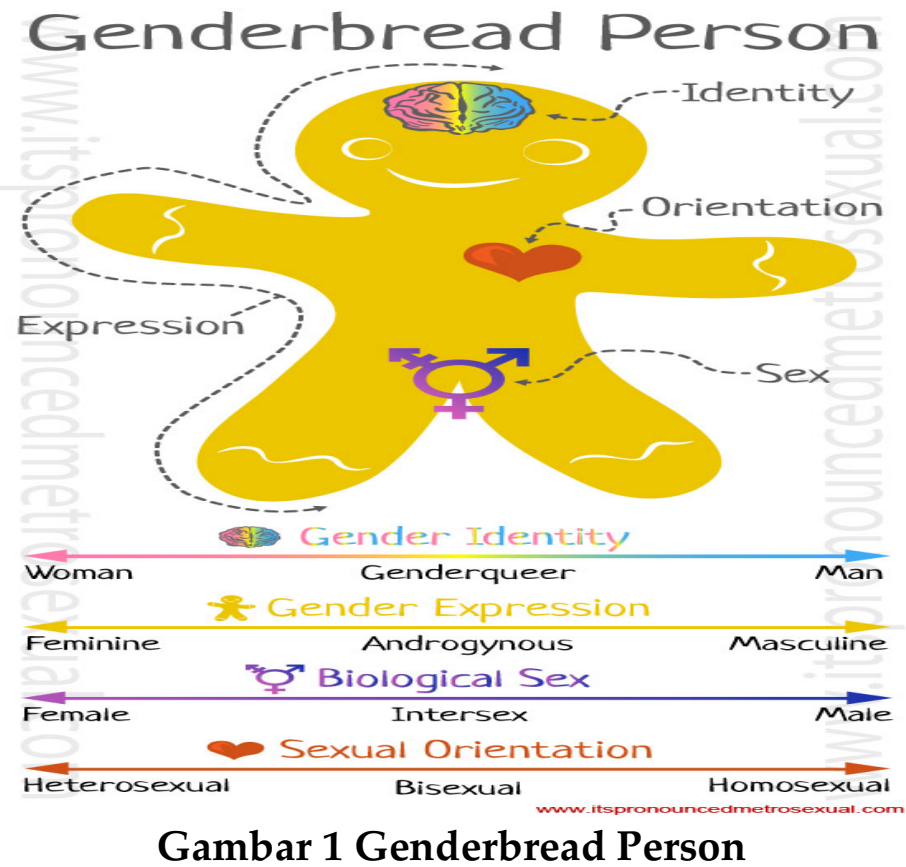

Sumber: www.itspronouncedmetrosexual.com 
Gayle Rubin (1984: 159-160), seorang antropolog feminis kemudian mengatakan bahwa minoritas seksual adalah segala seksualitas yang berlawanan dengan seksualitas hetero. Di sini minoritas seksual termasuk segala seksualitas homoseksual, transeksual, dan segala jenis seksualitas yang tidak sejalan dengan seksualitas hetero. Menurut Kadir (2007:59) heteronormativitas muncul menjadi norma seksualitas yang dominan pada abad ke-18 saat seksualitas direpresi tanpa kekerasan. Kontrol dilakukan melalui berbagai macam regulasi di masyarakat sehingga heteronormativitas dianggap sebagai satu-satunya seksualitas yang sah. Dalam masyarakat kontemporer, seksualitas yang nonheteronormatif pun bukanlah fenomena yang aneh. Pada tahun 1920 dilaporkan bahwa orientasi seksual sesama jenis perempuan mencapai $23 \%$ dari total sampel 2.200 perempuan yang diobservasi di Amerika. Hasil serupa juga dikonfirmasi lagi pada tahun 1940 yang menemukan bahwa setidaknya 20\% dari 2.601 perempuan yang diobservasi memiliki kecenderungan orientasi seksual homoseks. Begitu juga dengan homoseksualitas antara sesama lakilaki. Pada tahun 1948 setidaknya 20\% dari 2.830 laki-laki yang diobservasi menyatakan bahwa mereka merasakan orgasme ketika melakukan hubungan seksual homoseks (Kadir, 2007: 85).

Banyak pekerja yang sebenarnya memiliki seksualitas yang non-heteronormatif seperti homoseksual dan transeksual. Dalam sebuah riset yang dilakukan oleh Overby dan Barth (2006: 202) di Amerika Serikat yang menanyai responden jumlah estimasi orangorang di lingkungan tempat mereka tinggal yang memiliki seksualitas non-heteronormatif (terutama homoseksual) menemukan bahwa rata-rata responden menyatakan $7.68 \%$ dari total populasi di mana mereka tinggal memiliki seksualitas non-heteronormatif. Kecenderungan saat ini, banyak tempat kerja yang mulai mencoba menghapuskan diskriminasi yang didasarkan pada seksualitas. Banyak tempat kerja kemudian menganggap seksualitas sebagai suatu keragaman atau diversity yang memperkaya seperti halnya keragaman dalam ras dan agama. Akan tetapi, Aaron dan Ragusa 
(2011: 625-626) menyatakan bahwa walau secara formal diskriminasi berdasarkan seksualitas mulai dilarang terutama di banyak negara barat pada kenyataannya diskriminasi itu masih ada hanya saja dilakukan secara tertutup, terselubung, atau tidak langsung (covert). Oleh sebab itu, banyak para pekerja minoritas seksual tetap memilih untuk menutupi seksualitasnya alih-alih membuka diri atau melakukan coming out.

Coming out atau pengungkapan diri adalah suatu aksi bagi orang-orang dengan seksualitas minoritas untuk mengungkapkan seksualitasnya tersebut kepada orang lain. Menurut Griffith dan Hebl (2002: 1196), para pekerja dengan minoritas seksual yang melakukan coming out di tempat kerja mereka dan kemudian memiliki lingkungan kerja yang suportif terhadap seksualitas mereka dilaporkan mempunyai tingkat kepuasan kerja yang tinggi dan kecemasan kerja yang rendah. Akan tetapi, banyak orang-orang yang memiliki seksualitas minoritas lebih memilih untuk closeted alih-alih coming out karena proses pengungkapan diri terkait seksualitas sering kali merupakan aktivitas yang emosional dan melelahkan secara psikis. Walau begitu, closeted jauh lebih berisiko secara psikis daripada coming out. Hasil penelitian menunjukkan bahwa orang-orang yang memilih untuk menutup diri (closeted) cenderung memiliki tingkat kesejahteraan psikososial yang rendah, begitu juga kepuasan hidupnya rendah. Orang-orang yang memilih untuk closeted juga dilaporkan memiliki risiko kesehatan yang lebih tinggi dibandingkan dengan orang-orang yang memilih untuk coming out. Hal ini disebabkan karena adanya beban yang membuat orang-orang tersebut harus berpura-pura memiliki seksualitas yang heteronormatif walaupun sebenarnya tidak.

\section{PEMIKIRAN ALAIN BADIOU Matematika sebagai Ontologi}

Alain Badiou adalah seorang pemikir yang hidup dalam tradisi Marxis. Ini terlihat dari latar belakang keluarganya yang merupakan keluarga "merah" di Perancis. Badiou sepakat dengan pemikiran 
Marx terutama terkait dengan perjuangan emansipasi dan perlunya mengubah dunia. Akan tetapi, Badiou keberatan dengan cara yang ditempuh Marx. Marx berkata bahwa sekarang saatnya mengubah dunia alih-alih menafsirkan dunia. Pernyataan ini, menurut Badiou, berimbas pada berakhirnya filsafat dan beralih ke dalam praksis. Filsafat Badiou bermula dari penolakannya terutama pada pemikiran Posmodern yang menyatakan kematian metafisika dan menolak adanya kebenaran. Bagi Posmodern, yang ada adalah diskursus yang memiliki kebenaran-kebenarannya sendiri. Bagi Badiou, ini membuat filsafat menjadi tidak berguna. Hasrat utama filsafat justru adalah mencapai kebenaran. Dengan hasratnya ini filsafat kemudian berusaha mewujudkan usaha emansipatorisnya dan memberikan kontribusi kepada jalannya perubahan. Norris (2009: 3) salah satu penulis yang menulis buku pengantar terhadap pemikiran Badiou menyatakan bahwa Badiou memiliki keprihatinan akan kondisi filsafat saat ini yang seolah-olah lumpuh.

Walaupun mengkritik Marx, tetapi Badiou tetaplah seorang yang terinspirasi dengan pemikiran-pemikiran Marx. Cara pembacaan Badiou terhadap Marx terpengaruh oleh cara pembacaan Althusser. Althusser melihat bahwa sejarah masyarakat itu tak lain adalah sejarah yang berdasar pada materialisme dialektis. Seperti Marx, Althusser berpendapat bahwa struktur masyarakat terdiri dari dua bagian besar yaitu basis struktur dan suprastruktur. Basis struktur adalah relasi ekonomi, sedangkan suprastruktur adalah ideologi dan negara. Bagi Marx, perubahan dalam suprastruktur hanya memungkinkan apabila basis struktur berubah. Oleh karenanya, perubahan hanya dimungkinkan dimulai dari basis yaitu dengan cara mengubah relasi ekonomi di dalam masyarakat yang borjuis. Apabila basis struktur ini berubah, maka niscaya suprastruktur pun akan berubah. Althusser memahami hubungan antara basis dan suprastruktur ini agak berbeda dari Marx. Bagi Althusser, basis struktur dan suprastruktur memiliki hubungan yang kompleks dan interdependen (saling tergantung satu sama lain). Pemikiran Althusser tentang Marx ini kemudian diradikalkan oleh 
Badiou misalnya terkait dengan pemikiran filsafat politik yang berbeda dengan metapolitik. Saat filsafat politik mendekati politik dari luar politik (misalnya melalui etika) maka metapolitik mendekati politik dari dalam politik itu sendiri. Badiou menjelaskan emansipasi dan perubahan politik terjadi di dalam politik itu sendiri dan bukan di luar politik. Bagi Badiou, praksis harus didasari oleh ontologi layaknya Marx mendasarkan materialisme historis melalui materialisme dialektis (Suryajaya, 2011: 38-74).

Badiou juga merupakan seorang aktivis Marxis yang aktif dalam pergerakan kiri di Perancis. Di dalam Suryajaya (2011: 1-16) dijelaskan keterlibatan Alain Badiou dalam gerakan mahasiswa Perancis 1968 yang menolak rezim De Gaulle. Rezim De Gaulle dianggap pro kolonialisme dengan menolak dekolonisasi daerah jajahan Perancis terutama Aljazair. Rezim De Gaulle juga dianggap imperialis dengan mendukung perang Vietnam. Selain itu, rezim De Gaulle juga dianggap tidak becus dalam mengurus ekonomi Perancis sehingga terjadi tingkat inflasi yang tinggi. Pergerakan mahasiswa 68 ini dianggap Badiou sebagai wujud nyata dari konkritisasi teori Marx di mana massa yang teralinenasi melakukan perlawanan melalui aksi revolusi. Akan tetapi, Badiou pun kemudian dikecewakan oleh peristiwa 68 ini karena ternyata pergerakan ini malah dengan suksesnya berhasil "ditumpas" oleh rezim De Gaulle dan malah seolah-olah menvalidasi rezim tersebut. Badiou kemudian melihat, bahwa sebelum sebuah praksis dijalankan maka harus dipikirkan dulu terkait dengan Ada. Filsafat selama ini, termasuk filsafat Marxis, telah melupakan persoalan tentang Ada dan berfokus pada praksis semata. Akibatnya filsafat menjadi runtuh dan tak berdaya dalam melakukan emansipasi karena tiadanya kebenaran yang melandasinya. Untuk memperbincangkan Ada ini, bagi Badiou hanya matematika yang mampu menjelaskan Ada secara gamblang dan menyeluruh. Bahasa umum yang kita pakai terlalu miskin untuk menjelaskan $A d a$. Oleh sebab itu, Heidegger berlari pada puisi dalam menjelaskan $A d a$. Tetapi bagi Badiou, matematika lebih memadai dalam menjelaskan Ada. Bagi Badiou, bahasa selalu 
merujuk kepada sesuatu di luar dirinya sehingga seringkali bahasa terjebak di dalam konsep-konsep yang membatasi ketika memperbincangkan Ada.

Lalu bagaimana caranya menjelaskan ontologi dengan matematika? Bagi Badiou, semua itu dapat dijelaskan dengan teori himpunan atau set theory. Teori himpunan memungkinkan penjelasan mengenai bagian dari bagian atau kumpulan dari kumpulan. Misalnya menjelaskan baju-baju yang tersimpan dalam lemari. Lemari yang merupakan bagian dari furniture yang ada dalam kamar. Kamar adalah bagian ruangan di rumah. Rumah adalah salah satu bangunan dalam satu komplek. Komplek adalah satu bagian dari sebuah kota. Kota adalah bagian dari suatu provinsi. Provinsi bagian dari suatu negara. Negara bagian dari dunia. Dunia bagian dari sistem tata surya. Sistem tata surya bagian dari galaksi bimasakti, dan seterusnya sampai tidak terhingga.

Anggota dari suatu himpunan pasti adalah merupakan himpunan juga. Oleh sebab itu, anggota dari suatu himpunan merupakan himpunan dari himpunan. Persoalan utama yang dijelaskan oleh teori himpunan adalah terkait dengan relasi. Relasi yang terjadi dalam teori himpunan adalah relasi antara himpunan dengan elemen atau anggotanya atau antara satu himpunan dengan himpunan yang lain. Di dalam himpunan; satu, banyak, dan kosong dapat berada secara bersamaan. Satu sebenarnya adalah selalu banyak atau jamak atau multiple. Atribut satu di dalam himpunan tak lain adalah dari proses operasi penghitungan sebagai satu atau count-as-one. Yang ada adalah proses penghitungan menjadi satu. Ini berarti Ada yang adalah kejamakan dari kejamakan yang bersifat sampai tak terhingga, kemudian dihitung sebagai satu ketika ia masuk sebagai elemen atau anggota suatu himpunan. Inilah yang disebut oleh Badiou sebagai proses strukturisasi yaitu saat kejamakan-kejamakan mengalami proses penghitungan sebagai satu di dalam situasi. Saat proses strukturisasi ini tidak terjadi maka yang Ada adalah kejamakan-kejamakan yang tidak terhitung sebagai satu satuan. Merujuk pada ontologi yang dijelaskan Badiou, Ada adalah 
kejamakan dari kejamakan dan yang satu adalah kejamakan yang dihitung sebagai satu sedangkan yang Tidak Ada atau kekosongan atau void adalah kejamakan yang tidak terhitung sebagai satu walaupun keberadaannya selalu terdapat di setiap himpunan. Kekosongan ini adalah himpunan kosong yang dilambangkan dengan notasi $\varnothing$ (Badiou, 2006: 23-48)

Proses strukturisasi terjadi pada saat penghitungan sebagai satu, dan proses penghitungan ini yang menciptakan situasi. Situasi inilah yang bila merujuk pada pemikiran Althusser adalah struktur di dalam masyarakat. Sebelum adanya proses strukturisasi melalui penghitungan ini, Ada yang merupakan kejamakan hanyalah kejamakan yang sifatnya inkonsisten (Badiou, 2006: 29).

\section{Presentasi}

Konsep presentasi menekankan bahwa Ada sebagai kejamakan terlihat dan dihitung sebagai elemen di dalam suatu himpunan. Misalnya jika unggas terpresentasi dalam himpunan A, maka unggas akan dihitung sehingga apabila unggas tidak ada dalam himpunan A jumlah anggota himpunan A akan berkurang. Di sini, presentasi dianggap sebagai yang $A d a$, karena setiap elemen terhitung sebagai satuan. Yang $A d a$ dalam presentasi adalah kejamakan karena bagi Badiou setiap anggota dari suatu himpunan adalah pasti juga adalah himpunan. Selain itu, yang Ada dalam presentasi ini disebut juga sebagai kejamakan yang konsisten, disebut konsisten karena yang Ada ini sudah mengalami proses penghitungan sebagai satu atau count-as-one sehingga ke-Ada-annya tampak dan dianggap sebagai elemen yang bernilai satu. Presentasi atau belonging menjadi dasar relasi dari himpunan. Presentasi mendaftar anggota himpunan di dalam situasi dan karenanya menjadi pokok dari proses strukturisasi. Proses strukturisasi sendiri adalah proses pemilahan kejamakan-kejamakan ke dalam situasi melalui proses penghitungan. Dasar dari proses penghitungan itu sendiri adalah keanggotaan kejamakan di dalam situasi. Oleh sebab itu, situasi selalu distrukturkan oleh kejamakan-kejamakan yang 
telah melalui proses penghitungan. Yang satu artinya yang terhitung sebagai satu di dalam proses strukturisasi. Di sini elemen atau anggota atau presentasi dilambangkan dengan notasi $\in$. Maka presentasi tidak lain adalah relasi belonging (Badiou, 2006: 81-85).

\section{Representasi}

Relasi berikutnya dalam teori himpunan adalah relasi ketercantuman atau inclusion. Inilah juga kemudian yang disebut sebagai representasi. Representasi oleh karenanya adalah Ada yang hadir dalam situasi secara tidak langsung, karena ia merupakan anggota yang diperanggotakan. Ia juga berarti merupakan himpunan bagian dari suatu himpunan. Representasi dinotasikan dengan lambang $\subset$. Akan tetapi, pada dasarnya relasi keanggotaan atau belonging adalah relasi yang utama. Hal ini disebabkan karena relasi ketercantuman tidak lain adalah relasi yang dapat dijelaskan oleh relasi keanggotaan karena ketercantuman tidak lain adalah relasi keanggotaan ganda. Oleh sebab itu, jumlah elemen dalam representasi selalu lebih besar dari presentasi karena representasi mencakup seluruh himpunan bagian. Himpunan bagian adalah elemen satu persatu yang dipecah dan apabila dijumlahkan jumlah himpunan bagian ini akan selalu mengikuti rumus $2^{n}$ di mana $n$ adalah jumlah elemen atau anggota atau presentasi dari himpunan yang dipecah ke dalam himpunan-himpunan bagian.

Badiou mendefinisikan representasi sebagai: Count of the count, metastructure, inclusion, subset and part are on the side of the state of the situation(Badiou, 2005: 103). Di dalam konsep presentasi ada satu bagian yang tidak terhitung sebagai elemen, walaupun ketika dijabarkan dalam representasi bagian itu ada. Itu adalah himpunan kosong. Oleh sebab itu, himpunan kosong adalah bagian yang selalu menstrukturkan sebuah himpunan. Ia $A d a$ walaupun tidak terpresentasi.

Sekarang contoh himpunan pekerja digunakan untuk menjelaskan konsep representasi ini. Apabila ketenagakerjaan adalah sebuah situasi atau himpunan para pekerja maka di dalam 
himpunan tersebut selalu ada bagian yang Ada tetapi tidak terhitung sebagai elemen. Keberadaannya diketahui ketika situasi tersebut dijabarkan dalam himpunan bagian yaitu sebagai himpunan kosong. Himpunan kosong inilah para pekerja yang tidak terhitung sebagai elemen dari himpunan pekerja misalnya pekerja minoritas seksual, pekerja ilegal, dan pekerja dalam sektor ekonomi informal. Keberadaan mereka Ada tetapi tidak terhitung dalam himpunan pekerja oleh sebab itu menjadi Tidak Ada. Padahal jika situasi ketenagakerjaan dijabarkan ke dalam himpunan-himpunan bagiannya, maka di sana terdapat himpunan kosong sebagai salah satu himpunan bagian. Akibatnya mereka (pekerja yang tidak terhitung sebagai elemen dalam himpunan pekerja atau tidak terpresentasi) tidak memperoleh perlindungan dan penghargaan yang diperoleh oleh para pekerja yang terpresentasi dalam situasi ketenagakerjaan.

Apa yang harus dilakukan kemudian? Para pekerja ini harus memunculkan dirinya sehingga dapat terhitung dalam himpunan pekerja sebagai elemen bukan lagi sebagai himpunan kosong. Bagi pekerja minoritas seksual, cara memunculkan diri ke dalam presentasi adalah dengan melakukan coming out yaitu membuka diri terkait dengan seksualitasnya. Dengan membuka diri maka pekerja minoritas seksual akan terhitung dalam himpunan pekerja. Artinya situasi ketenagakerjaan juga terstruktur oleh pekerja minoritas seksual karena mereka telah terhitung sebagai satu atau count-as-one.

Bagaimana memunculkan yang Tidak Ada menjadi Ada? Ini dapat dilakukan menurut Badiou melalui suatu aksi yang disebut peristiwa atau event. Di dalam peristiwa kejamakan yang Tidak Ada ini akan muncul ke dalam presentasi oleh karenanya terstruktur dalam situasi.

\section{Peristiwa}

Di bagian sebelumnya telah dijelaskan terkait dengan presentasi dan representasi.Terpresentasi berarti terhitung sebagai elemen di dalam situasi, sedangkan ter-representasi adalah menjadi 
bagian di dalam situasi atau keanggotaan yang diperanggotakan. Saat ada kejamakan yang luput dari proses strukturisasi atau proses penghitungan sebagai satu, maka ia akan tinggal sebagai kejamakan yang inkonsisten yang keberadaannya dapat diidentifikasi melalui penjabaran himpunan ke dalam himpunan-himpunan bagiannya (atau melalui representasi).

Lebih lanjut Badiou menjelaskan hubungan antara presentasi dengan representasi ini ke dalam beberapa kategori.Kategori pertama adalah kategori normal atau natural. Kategori ini adalah saat suatu kejamakan (ingat himpunan selalu terdiri atas himpunanhimpunan, maka disebut sebagai kejamakan) terpresentasikan dan juga ter-representasikan. Di sini tidak ada ekses karena kejamakan terpresentasi juga sekaligus ter-representasi. Bagi Badiou contoh kondisi normal atau natural ini adalah himpunan bilangan asli (natural number) atau $\mathbb{N}$. Bilangan asli adalah bilangan bulat positif dan nol. Himpunan bilangan asli berarti adalah himpunan bilangan dari 0, 1, 2, 3, 4 dan seterusnya. 0 adalah himpunan kosong, 1 adalah himpunan yang elemennya adalah himpunan kosong, 2 adalah himpunan yang elemennya 0 dan 1, serta 3 adalah himpunan yang elemennya 0, 1, dan 2 dan seterusnya (Badiou, 2006: 104-111).

Kategori kedua yang menjelaskan hubungan antara presentasi dengan representasi adalah kategori historis. Di dalam kategori ini selalu ada kesenjangan antara presentasi dengan representasi. Kategori historis ini terbagi menjadi singular yaitu terpresentasi tetapi tidak ter-representasi dan kategori excrescences atau khusus yaitu tidak terpresentasi tetapi ter-representasi. Menurut Badiou, kategori historis inilah yang ada dalam situasi sosial politik (Badiou, 2006: 174).

Mari ambil contoh dalam menjelaskan situasi ketenagakerjaan, maka selalu ada kesenjangan antara yang terpresentasi dengan yang ter-representasi. Misalnya pekerja minoritas seksual selalu tidak terpresentasi tetapi ia ter-representasi di dalam kejamakan yang inkonsisten. Dalam kategori yang historislah menurut Badiou peristiwa atau event muncul. 
Dikarenakan situasi tidak akan pernah mengakui peristiwa, maka diperlukan intervensi yaitu prosedur pengakuan kejamakan sebagai peristiwa. Wujud dari intervensi ini adalah proses penamaan peristiwa atau nomination. Agar peristiwa diakui sebagai elemen dalam situasi, maka diperlukan keteguhan dalam mengikuti peristiwa tersebut inilah yang disebut sebagai fidelity. Lalu bagaimanakah sebuah peristiwa kemudian menjadi elemen di dalam situasi? Inilah yang disebut sebagai forcing yaitu suatu penambahan (atau perluasan/extension dalam terminologi Badiou) dari yang generik ke dalam situasi awal. Inilah juga yang disebut sebagai truth procedure. Yang generik atau yang tak terpilah atau kebenaran ini dinotasikan dalam simbol + . Yang generik ini menurut Badiou terdapat dalam quasi-complete situation atau disimbolkan dengan $\mathrm{S}$ (Badiou, 2006: 355-362).

Di dalam $S$ inilah sebagai quasi-complete situation maka dimungkinkan munculnya $q$ atau yang generik atau yang tak terpilah (indiscernible) atau kebenaran sebagai perluasan generik atas $S$ atau $S(+)$ yaitu himpunan baru yang diperoleh dengan menambahkan elemen positif dengan yang tak terpilah. Persis pada titik inilah Badiou membuktikan bahwa dimungkinkan untuk menambahkan elemen dalam situasi dari dalam situasi itu sendiri. Inilah yang disebut metapolitik, yaitu politik yang dilihat dari dalam politik itu sendiri bukan dari luar. Di sini Badiou melalui matematika membuktikan bahwa peristiwa dapat muncul sebagai elemen dalam situasi dari dalam situasi itu sendiri. Ini berarti bahwa perjuangan emansipasi dapat ditempuh dari dalam arena sendiri alih-alih memaksakan dari luar arena (Badiou, 2006:363-365).

Lalu pertanyaan berikutnya siapakah yang melakukan forcing? Badiou menjawab ia adalah subjek. Akan tetapi subjek yang dipahami Badiou bukanlah subjek sebagai substansi, bukan pula subjek sebagai kekosongan atau void, bukan pula subjek sebagai hasil penginderaan empiris, bukan pula subjek sebagai efek presentasi yang homogen, bukan pula subjek sebagai keniscayaan, bukan pula subjek sebagai efek atau asal usul. Oleh karenanya, Badiou tidak 
merujuk subjek kepada suatu individu tertentu atau kepada aktor tertentu. Subjek justru muncul saat ada penggabungan diri dengan peristiwa. Subjek oleh karena itu dapat jadi satu individu atau kumpulan dari individu. Subjek adalah efek dari peristiwa dan bagian dari prosedur generik. Di sini subjek dipahami berbeda dengan pemahaman subjek yang selama ini dipahami dalam filsafat yang melihat subjek sebagai esensi, sebagai ke-diri-an, sebagai ego, atau sebagai ke-Aku-an (Badiou, 2006: 391-394).

Kebenaran yang selama ini selalu digaungkan oleh Badiou yang mendasari kritiknya pada Posmodern terletak pada peristiwa. Kebenaran dan peristiwa oleh karenanya terkait erat. Badiou menyebutnya truth-event. Kebenaran bagi Badiou identik dengan yang tak terpilah (indicernable) atau yang generik ( $($ ). Kebenaran ini adalah efek dari peristiwa, yaitu kejamakan yang tidak terpilah di dalam situasi tetapi ada di dalam situasi dan baru muncul melalui peristiwa. Kebenaran tidak muncul dalam situasi karena di dalam situasi elemennya selalu pasti sudah terpilah sesuai dengan sifat atau property yang melandasi situasi padahal kebenaran adalah sesuatu yang tidak terpilah.

Untuk meringkas bagian ini maka disimpulkan bahwa peristiwa diawali oleh penamaan atau nomination, lalu intervensi (yang diwujudkan dalam proses penamaan itu sendiri), dilanjutkan dengan fidelity yaitu keteguhan dalam mengikuti peristiwa atau efek waktu dari peristiwa, dan forcing yaitu perluasan situasi S dengan menambakan yang tak terpilah atau + yang muncul dari dalam $S$ itu sendiri.

Peristiwa menambahkan elemen yang tidak terpresentasi ke dalam situasi karena elemen di dalam situasi telah mengalami pemilahan sifat yang sesuai dengan situasi. Peristiwa justru menambahkan elemen yang tidak terpilah dari dalam situasi itu sendiri dan kemudian menjadikannya sebagai elemen di dalam situasi yang kemudian mengubah struktur situasi dari $S$ menjadi $\mathrm{S}($ ㅇ). 
Prosedur generik yang menampilkan yang tak terpilah (ㅇ) ke dalam situasi ini dilakukan oleh subjek sebagai yang memastikan bahwa peristiwa tersebut dikenali dalam situasi dan pada akhirnya mengubah struktur dalam situasi di mana terjadi penambahan elemen di dalam situasi bukan dari luar tetapi dari dalam situasi itu sendiri.

\section{COMING OUT SEBAGAI STRATEGI PRESENTASI MELAWAN DISKRIMINASI}

Rasmussen (2004: 144) mengungkapkan coming out terkait erat dengan inklusivitas (inclusivity). Coming out akan memberikan upaya untuk mengurangi sikap homofobia yaitu sikap yang antipati terhadap orientasi seksual sejenis dan heteroseksis yaitu sikap yang menganggap seksualitas hetero sebagai satu-satunya seksualitas yang ideal. Hal ini disebabkan karena coming out akan memberikan kontak personal secara satu-satu atau one-on-one. Selama ini homofobia dan heteroseksis umumnya didasarkan pada prasangka atau prejudice karena tidak adanya contoh riil atau kontak riil dari orang-orang yang memiliki seksualitas minoritas. Mereka sering kali dianggap sebagai bagian yang lain yang terpisah dari keseharian saat ini.

Coming out karena itu terkait dengan inklusivitas karena coming out menghadirkan pengalaman interaksi yang langsung antara orang dengan seksualitas minoritas terhadap orang dengan seksualitas mayoritas yang heteronormatif. Sebaliknya, hiding in the closet atau closeted terkait erat dengan eksklusivitas. Hal ini disebabkan closeted menjadikan tidak memungkinkan adanya kontak dan interaksi yang personal. Orang-orang dengan minoritas seksual dianggap tidak berada diantara kita dan tetap menjadi bagian yang terpisahkan dari kita. Hal ini akan membuat prasangka terhadap orang-orang dengan minoritas seksual menjadi negatif. Lebih jauh, Rasmussen (2004: 144145) mengatakan bahwa coming out adalah suatu tindakan yang imperatif, yang harus dilakukan. Sedangkan closeted adalah suatu 
tindakan yang justru dianggap sebagai tindakan yang meninggalkan kewajiban.

Pekerja minoritas seksual selalu menjadi bagian dari situasi ketenagakerjaan. Hal ini dapat diketahui melalui penjabaran situasi ketenagakerjaan sebagai himpunan ke dalam himpunan-himpunan bagiannya. Di dalam setiap himpunan selalu ada bagian berupa himpunan kosong yang disimbolkan dengan $\emptyset$ yang melandasi setiap himpunan tetapi tidak pernah menjadi elemen himpunan itu sendiri (ter-representasi tetapi tidak terpresentasi). Pekerja minoritas seksual kemudian selalu menjadi himpunan kosong. Ia menjadi bagian tapi tidak terhitung sebagai elemen dalam situasi. Mengapa hal ini terjadi?

Hal ini dapat terjadi karena umumnya pekerja minoritas seksual memilih strategi hiding in the closet karena dianggap sebagai strategi yang paling aman, atau dianggap sebagai strategi survival. Closeted dianggap sebagai pilihan paling rasional di tengah masyarakat yang menganut norma seksualitas yang heteronormatif sebagai norma yang dominan yang tidak memberikan ruang bagi seksualitas di luar itu. Pengalaman akan kekerasan yang dialami oleh orang-orang dengan seksualitas yang minoritas dianggap menjadi pembenaran untuk tetap menyembunyikan diri dan berpura-pura.

Bentuk diskriminasi yang diterima oleh korban di tempat kerja umumnya berupa praktik-praktik yang dianggap memberikan kerugian bagi mereka. Mulai dari kekerasan baik secara fisik maupun verbal sampai dengan praktik SDM yang tidak berpihak. Horta (2015: 277) mengatakan bahwa suatu aktivitas dikatakan diskriminatif apabila: As some form of differential consideration or treatment which, among other features, entails a disadvantage for discriminatees.

Akan tetapi, seiring berjalannya waktu saat ini diskriminasi dilakukan tidak secara terbuka dan lebih secara halus. Banyak pihak merasa bahwa diskriminasi telah hilang tetapi sebenarnya diskriminasi tetap ada secara laten. Bagi Horta (2015: 277-279), 
definisi diskriminasi yang mengharuskan adanya korban yang menderita kerugian dari suatu perbuatan dianggap tidak lagi relevan. Hal ini disebabkan karena sering kali diskriminasi dilakukan secara lebih halus dan tidak terungkap serta tidak ditujukan secara langsung.

Seseorang yang mengalami diskriminasi pun sering kali tidak sadar bahwa dirinya menjadi korban karena tidak adanya kerugian yang dia alami yang dia rasakan secara langsung. Di beberapa perusahaan sering kali pekerja minoritas seksual mendapatkan perlakuan yang sifatnya mengarah pada kekerasan atau perlakuan ketenagakerjaan yang tidak adil. Tetapi, di beberapa perusahaan lain yang walaupun telah dianggap menerapkan aturan anti-diskriminasi ternyata sering kali diskriminasi masih ditemui dalam bentuk yang paling halus seperti stigmatisasi dan labelisasi walaupun kadang hal tersebut tidak diungkapkan secara langsung.

Ketakutan akan perlakuan tidak adil dan tindakan kekerasan menyebabkan pekerja minoritas seksual tidak mau terbuka terkait seksualitasnya di tempat kerja. Inilah yang menyebabkan pekerja minoritas seksual tetap menjadi himpunan kosong dalam situasi ketenagakerjaan. Keberadaan mereka tidak pernah terhitung karena kecenderungan untuk menutup diri. Di sini ada tidaknya diskriminasi dianggap sebagai faktor pendorong seseorang untuk coming out atau closeted. Jika diskriminasi dirasa tidak ada maka pekerja seksual minoritas akan melakukan coming out dan jika diskriminasi dirasa tinggi strategi yang dianggap baik adalah closeted. Pola pikir inilah yang terbalik.

Diskriminasi justru adalah akibat dari keputusan para pekerja minoritas seksual untuk menyembunyikan seksualitasnya. Dengan closeted atau menyembunyikan seksualitasnya, pekerja minoritas seksual tidak akan pernah dapat tampil ke dalam situasi, tidak akan pernah terpresentasi. Karena tidak ada di dalam situasi (atau tidak menjadi elemen, atau tidak terpresentasi) maka adalah suatu hal yang menggelikan apabila pekerja minoritas seksual tiba-tiba mengharapkan suatu lingkungan kerja yang suportif bagi seksualitas 
mereka dan membuat mereka dengan leluasa membuka seksualitasnya. Hal ini terjadi karena apabila situasi ketenagakerjaan adalah S, maka $S$ ini tidak mengenal yang lain-lain yang tidak menjadi anggota atau elemen dari S. Pekerja minoritas seksual tidak ada dalam $S$ dan bukan elemen $S$.

Ada atau tidak adanya diskriminasi di tempat kerja bukanlah faktor penyebab untuk coming out bagi pekerja dengan seksualitas minoritas. Diskriminasi justru menjadi faktor akibat dari strategi closeted yang dipilih. Dengan closeted pekerja minoritas seksual tidak akan pernah terpresentasi sebagai elemen dalam situasi ketenagakerjaan. Akibatnya mereka selalu dianggap bukan sebagai elemen, bukan sebagai anggota, dianggap sebagai himpunan kosong. Coming out sebagai peristiwa membuat dirinya masuk sebagai elemen dalam situasi. Coming out akan menyatakan bahwa ada himpunan yang tak terpilah atau indiscernible di dalam situasi atau ada +di dalam S. Apabila $S$ adalah situasi ketenagakerjaan yang distrukturkan dalam seksualitas sehingga melakukan pemilahan terhadap elemennya, maka $q$ sesungguhnya terdapat dalam $S$ tetapi ia tidak terpilah sebagaimana elemen yang terhitung di dalam $S$ sehingga kondisi $S($ ( ) ) sebenarnya adalah niscaya.

Hanya saja, untuk membuat $q$ yang merupakan perluasan dari situasi ketenagakerjaan $\mathrm{S}$ di mana $q$ adalah kebenaran yang menyatakan bahwa pekerja minoritas seksual adalah bagian dari $\mathrm{S}$ yang diperluas, maka diperlukan intervensi. Karena $q$ tidak akan serta merta muncul dalam $S$ karena $q$ tidak terpilah dalam $S$ dan berakibat tidak dikenali oleh $S$. Intervensi ini adalah proses penamaan atau nomination dari peristiwa. Membuka identitas seksual pekerja minoritas seksual kemudian disebut sebagai coming out untuk membuatnya ternamai sebagai peristiwa. Supaya coming out diakui sebagai himpunan peristiwa $(p|\varnothing|=\varnothing,\{\varnothing\}$ atau coming out dan himpunan coming out yang memiliki elemen (pekerja minoritas seksual) maka diperlukan dimensi waktu dalam peristiwa atau fidelity yaitu keteguhan untuk mengikuti coming out sampai dengan batas implikasi yang paling jauh (misal menerima cemoohan, 
hinaan, bahkan mungkin perlakuan kekerasan). Fidelity terhadap coming out ini lama kelamaan akan membuat coming out dapat termasuk sebagai elemen $S$ atau elemen dari situasi ketenagakerjaan melalui proses forcing yaitu proses yang melakukan perluasan $\mathrm{S}$ dengan menambahkan $\circ$ menjadi $S(+)$.

q inilah yang disebut sebagai kebenaran, yaitu adanya himpunan pekerja dengan seksualitas minoritas yang tidak terpilah dalam situasi ketenagakerjaan $S$ karena situasi ketenagakerjaan $S$ hanya memilah elemen atau anggota yang sesuai dengan sifat/property yang menjadi ensiklopedia situasi. Ensiklopedia ini adalah seksualitas heteronormatif. Pemilahan berdasar sifat seksualitas heteronormatif membuat pekerja minoritas seksual yang non-heteronormatif tidak terhitung sebagai elemen S. Maka dengan forcing, $\rightarrow$ akan memperluas $S$ menjadi $S(+)$ yang artinya himpunan pekerja minoritas seksual terhitung sebagai elemen di dalam situasi ketenagakerjaan S melalui peristiwa coming out. Oleh sebab itulah Badiou menyebut peristiwa sebagai truth procedure yaitu suatu prosedur yang membuat kebenaran muncul dalam situasi. Badiou juga selalu mengatakan bahwa peristiwa itu terkait erat dengan kebenaran dan menyebutnya sebagai truth-event.

Oleh sebab itu, lingkungan kerja yang adil tanpa diskriminasi bagi pekerja minoritas seksual bukanlah hadiah yang diberikan dari surga secara cuma-cuma, tetapi sebagai perjuangan yang harus diwujudkan. Perjuangan ini terwujud dengan perubahan struktur di dalam S, yang sebelumnya tidak mengenali pekerja minoritas seksual sebagai elemen $S$ menjadi mengenalinya sebagai elemen $S$ melalui perluasan dari $S$ menjadi $S(+)$. $q$ adalah yang tak terpilah (indiscernible) atau kebenaran, yaitu kejamakan yang tidak muncul dalam $S$ karena tidak terpilah sesuai dengan sifat yang membangun $S$ tetapi ada di dalam $S$ secara tidak terpilah. Untuk memunculkan $q$ ini maka menurut Badiou harus dilakukan intervensi melalui penamaan akan sebuah peristiwa. Peristiwa ini adalah aktivitas membuka diri yang dinamai sebagai coming out. 
Dengan terpresentasi pekerja minoritas seksual dapat melawan diskriminasi. Hal ini disebabkan, keberadaan pekerja minoritas seksual menjadi hal yang biasa di dalam situasi ketenagakerjaan. Pekerja minoritas seksual menjadi sesuai dengan ensiklopedia yaitu sifat/property yang mendasari situasi. Interaksi yang personal akan mampu memberikan pemahaman yang adil terhadap pekerja minoritas seksual. Diskriminasi dalam bentuk kekerasan dan perlakuan buruk yang diterima pekerja minoritas seksual disebabkan karena keberadaan mereka dianggap pencilan atau outlier. Jumlah pekerja minoritas seksual yang secara statistik sebenarnya signifikan menjadi tidak berarti karena jumlah yang mau membuka dirinya sedikit. Akibatnya, pekerja minoritas seksual yang telah lebih dulu coming out menjadi target perlakuan buruk karena dianggap jumlah mereka sebagai penyimpangan statistik dalam distribusi kelompok pekerja. Mereka kerap dianggap sebagai abnormal, aneh, dan keliru sehingga perlu diluruskan dan diperbaiki. Kondisi ini akan dapat berakhir apabila adanya fidelity terhadap peristiwa. Peristiwa membutuhkan dimensi waktu untuk dapat menjadi terpresentasi di dalam situasi. Coming out membutuhkan waktu sehingga coming out sebagaiultra-one (dihitung dua kali sebagai satu seperti himpunan pangkat dapat dianggap sebagai $p|\varnothing|=(\varnothing,\{\varnothing\})$ akan dikenali dalam situasi sebagai perluasan (dari $S$ menjadi $S(+)$ ).

Oleh karena itu, coming out di lingkungan kerja justru harus menjadi strategi utama para pekerja minoritas seksual untuk menunjukkan bahwa jumlah mereka signifikan sehingga dapat terpresentasi dalam situasi ketenagakerjaan. Diskriminasi tidak pernah menjadi sebab tetapi selalu menjadi akibat. Diskriminasi yang berbentuk kekerasan dan perlakuan yang merugikan hanya dapat dilawan dengan menunjukkan presentasi diri. Diskriminasi disebabkan karena keengganan pekerja minoritas seksual untuk coming out di lingkungan kerja mereka sehingga membatasi interaksi yang personal dengan kelompok pekerja lainnya. Keterbatasan kontak ini kemudian menjadikan munculnya stigmatisasi dan 
labelisasi karena adanya penilaian yang bias dan tidak relevan terhadap kelompok minoritas seksual. Kelompok ini dianggap sebagai the other atau liyan yang bukan menjadi elemen dari himpunan para pekerja. Lalu siapakah yang akan menjadi aktor perubahan yang mengubah situasi ketenagakerjaan? Inilah yang disebut Badiou sebagai subjek. Subjek muncul saat ada penggabungan antara diri dengan peristiwa sehingga terjadi forcing yaitu truth procedure di mana peristiwa dikenali dalam situasi dan mengubah struktur situasi dari S menjadi $S($ ( ) $)$.

Akan tetapi, Badiou menolak subjek sebagai seorang aktor utama atau pahlawan yang melakukan aksi perubahan. Bagi Badiou subjek bukanlah ke-Aku-an, bukan pula ego. Oleh karena itu, subjek dapat jadi individu atau kumpulan individu. Subjek akan hadir selama adanya penggabungan diri dengan peristiwa. Oleh sebab itu, suatu perbuatan yang keliru apabila pekerja minoritas seksual kemudian menggantungkan diri pada hanya suatu aktor tertentu dalam mendorong perubahan (misalnya para aktivis LGBTIQ+ atau Lesbian Gay Biseksual Transgender Interseks Queer dan seksulitas non-heteronomatif lainnya). Setiap pekerja minoritas seksual dapat secara sendiri-sendiri atau kolektif bersama-sama menjadi subjek yang melakukan forcing yaitu mengubah situasi ketenagakerjaan dengan memunculkan presentasi mereka ke dalam situasi melalui peristiwa coming out.

Coming out di lingkungan kerja akan membuat pekerja minoritas seksual menjadi terpresentasi, terlihat, dan terhitung. Presentasi akan membuat pekerja minoritas seksual menjadi elemen atau anggota yang keberadaannya tidak tersembunyi. Ketidaktersembunyian ini akan mendorong pada interaksi dan kontak yang lebih dekat serta personal. Akibatnya stigmatisasi dan labelisasi yang tidak adil terhadap kelompok pekerja minoritas seksual ini dapat dilawan. 


\section{SIMPULAN}

Coming out adalah suatu aksi pengungkapan diri bagi orangorang dengan seksualitas minoritas kepada orang lain. Pengungkapan seksualitas ini dilakukan karena adanya dominasi bahwa seksualitas yang ideal adalah seksualitas yang mengikuti norma heteronormatif sehingga seksualitas di luar norma tersebut (seperti lesbian, gay, biskesual, transgender, interseks, panseksual, aseksual, sado-masokis, dan segala variasi seksualitas lainnya) dianggap tidak ideal dan menjadi minoritas. Akibat adanya dominasi seksualitas hetero-normatif ini, semua orang dianggap akan memiliki seksualitas tersebut sehingga dengan coming out sesungguhnya mengungkapkan diri bahwa ada seksualitas lain di luar seksualitas yang berdasarkan heteronormativitas.

Presentasi adalah suatu konsep di dalam teori yang diformulasikan oleh Alain Badiou. Terpresentasi berarti terhitung sebagai elemen di dalam situasi. Terhitung sebagai elemen ini membuat kejamakan yang inkonsisten menjadi kejamakan yang konsisten. Bagi Badiou, Ada adalah suatu kejamakan dan menjadi Ada adalah menjadi terhitung di dalam situasi sebagai elemen atau anggota dan karenanya menjadi kejamakan yang konsisten. Oleh sebab itu, yang satu atau The One dalam konsep Badiou bukanlah suatu substansi tetapi yang satu adalah efek dari penghitungan kejamakan sebagai satu satuan di dalam situasi. Coming out adalah strategi presentasi karena coming out adalah peristiwa yang ultra-one atau terhitung dua kali yaitu sebagai dirinya sendiri (coming out) dan sebagai himpunan coming out yang memiliki elemen pekerja minoritas seksual. Coming out menjadi strategi presentasi karena coming out akan membuat pekerja minoritas seksual yang sebelumnya tersisih atau excluded dalam situasi ketenagakerjaan menjadi hadir dan terpresentasi. Pekerja minoritas seksual menjadi excluded karena ia tidak masuk sebagai elemen di dalam situasi $\mathrm{S}$ karena situasi $S$ memiliki sifat atau property tertentu dalam memasukkan elemennya (dalam hal ini sifat seksualitas dominan heteronormatif). Padahal pekerja seksualitas minoritas adalah 
kejamakan yang tak terpilah atau indiscernible di dalam $\mathrm{S}$ atau yang dilambangkan oleh o. Adalah dimungkinkan untuk mengubah situasi $S$ dengan melakukan perluasan atau extension dengan penambahan $q$ ke dalam $S$ menjadi $S(+$ ). Proses penambahan ini dilakukan melalui forcing dan hanya mungkin terjadi melalui peristiwa. Oleh sebab itu, coming out sebagai peristiwa kemudian menjadi strategi presentasi bagi pekerja minoritas seksual karena memungkinkan mereka untuk menjadi elemen $\mathrm{S}$ dan terhitung sebagai satu satuan di dalam $S$ dengan adanya perluasan $S$ menjadi $\mathrm{S}($ 우).

Selama ini, ada tidaknya diskriminasi selalu dianggap sebagai penyebab bagi pekerja minoritas seksual untuk closeted atau coming out. Apabila diskriminasi dirasa ada, maka dipilihlah closeted tetapi apabila diskriminasi dirasa tidak ada makan dipilihlah coming out. Merefleksikan pemikiran Badiou, maka diskriminasi tidak pernah sebagai sebab untuk closeted tetapi sebagai akibat dari closeted. Dengan closeted maka pekerja minoritas seksual tidak dikenali dalam $S$ dan dianggap sebagai yang excluded dalam rupa himpunan kosong. Akibatnya, tidak akan pernah terjadi kontak yang intens dan personal antara pekerja minoritas seksual dengan pekerja mayoritas seksual heteronormatif. Diskriminasi menjadi akibat dari closeted karena pekerja minoritas seksual tidak dikenali dalam situasi ketenagakerjaan yang disimbolkan sebagai S. Diskriminasi justru harus dilawan dengan cara memunculkan diri di dalam situasi melalui peristiwa coming out. Dengan hadir dalam presentasi maka pekerja minoritas seksual menjadi elemen atau bagian dari situasi ketenagakerjaan. Akan terjadi kontak dan interaksi yang intens di antara sesama elemen di dalam S. Pekerja minoritas seksual kemudian menjadi berdaya karena dikenali dalam situasi ketenagakerjaan dan dapat bersuara melawan perlakuan-perlakuan yang diskriminatif dan tidak adil terhadap mereka karena mereka juga adalah elemen yang menyusun situasi. Oleh sebab itu, coming out adalah strategi presentasi pekerja minoritas seksual di dalam situasi ketenagakerjaan. Presentasi ini pada akhirnya akan mampu 
melawan dan meniadakan diskriminasi bagi pekerja minoritas seksual karena mereka telah menjadi anggota atau elemen yang dikenali dalam situasi ketenagakerjaan. Diskriminasi karenanya bukanlah sebab tetapi selalu menjadi akibat.

Pemikiran Badiou merupakan sintesis dari gaya filsafat analitik yang berfokus pada pendekatan yang rigour dalam filsafat dan menolak klaim-klaim metafisika (termasuk bahasan ontologi) sebagai sesuatu yang tidak bermakna dan gaya filsafat kontinental yang justru menolak pendekatan filsafat analitik yang dianggap mereduksi cara berpikir hanya kepada scientific approach yang terverifikasi secara empiris. Badiou menawarkan keduanya, di satu sisi ia beranggapan bahwa pembahasan metafisika (terutama pembahasan ontologi) adalah pokok utama dalam filsafat yang tidak boleh ditinggalkan dan di satu sisi lain ia bersepakat dengan metode yang rigour dan ketat dalam melakukan argumen filosofis. Di sini Badiou memilih jalan matematika sebagai jalan yang memenuhi hal tersebut. Bagi Badiou, matematika mampu menjelaskan perkara ontologis tentang Ada melalui cara argumentasi yang ketat karena matematika selalu bersifat self-referential dalam penjelasannya, berbeda dengan bahasa yang selalu merujuk pada hal-hal di luar bahasa ketika melakukan penjelasan.

Pemikiran Badiou juga mampu menawarkan proses perjuangan emansipasi terutama bagi pihak-pihak yang teralienasi di dalam struktur sosial-politik seperti kelompok-kelompok minoritas seksual dan imigran yang tak berdokumen. Badiou menganggap perjuangan emansipasi dapat dilakukan dari dalam struktur sosial-politik tersebut tanpa perlu melakukan penghancuran atau destruksi dari luar tetapi melalui perluasan dari dalam struktur itu sendiri. Di sini Badiou memberikan optimisme bahwa perubahan masih dimungkinkan dari dalam, perubahan itu dapat terjadi melalui peristiwa yang pembuktiannya dapat dipertanggungjawabkan dalam pembuktian matematis. 


\section{DAFTAR PUSTAKA}

Aaron, D. J. \& Ragusa, A. T., 2011, “Policy implication of gay men's workplace experiences: Public service employees in Australia's Capital", Policy Studies Vol. 32 No. 6.

Alimi, M. Y., 2004, Dekonstruksi seksualitas poskolonial: Dari wacana bangsa hingga wacana agama, LKiS, Yogyakarta.

Badiou, Alain, 2006, Being and Event, Continuum, London.

Boellstroff, T., 2004, “The emergence of political homophobia in Indonesia: Masculinity and national belonging", Journal of Antropology Ethnos Vol.69 No. 4.

Boellstroff, T., 2005, "Between religion and desire: Being Muslim and gay in Indonesia", American Anthropologist Vol. 69 No. 4.

Dania, M., 2011, "Gender construction on Banyuwangi's legend", Jurnal Filsafat Vol. 21 No. 2. 2011, Fakultas Filsafat, Yogyakarta.

Fajrian, 2015, Penggalan Lara Gelayut LGBT, http://www.cnnindonesia.com/nasional/20150502172500-2350660/penggalan-lara-gelayut-lgbt/ diakses pada \& Februari 2017.

Griffith, K. H. \& Hebl, M. R., 2002, “The disclosure dilemma for gay men and lesbians: Coming out at work", Journal of Applied Psychology Vol. 87 No. 6.

Horta, O., 2015, “Does discrimination require disadvantage?", Moral philosophy and politics Vol. 2 No. 2.

http://itspronouncedmetrosexual.com/2015/03/the-genderbreadperson-v3/ diakses pada 6 Februari 2017.

Kadir, H. A., 2007, Tangan kuasa dalam kelamin: Telaah homoseks, pekerja seks, dan seks bebas di Indonesia, InsistPress, Yogyakarta.

Maharani, Septiana Dwiputri, 2009, "Perempuan dalam kearifan lokal suku Baduy", Jurnal Filsafat Vol. 19 No. 3. 2009, Fakultas Filsafat UGM, Yogyakarta. 
Muthmainnah, Lailiy, 2008, "Kritik feminis terhadap developmentalisme", Jurnal Filsafat Vol. 18 No. 3. 2008, Fakultas Filsafat UGM, Yogyakarta.

Norris, C., 2009, Badiou's Being and event a reader's guide, Continuum, London.

Oetomo, D., 2015, Waria Paling Sulit Mendapatkan Pekerjaan, http://www.cnnindonesia.com/nasional/20150430180922-2150407/waria-paling-sulit-mendapatkan-pekerjaan/ diakses pada 7 Februari 2017.

Overby, L. M. \& Barth, J., 2006, “Numeracy about minority populations: Americans' estimations of local gay population size", Polity Vol. 38 No. 2.

Rasmussen, M. L., 2004, "The problem of coming out", Theory into practice Vol. 43 No. 2.

Rubin, G., 1984, "Thinking sex: notes for a radical theory of the politics of sexuality" dalam Parker. R. \& Aggleton, P. (eds 2007). Culture, society, \& sexuality a reader $2^{\text {nd }}$ edition, Routledge, Oxon.

Suryajaya, M., 2011, Alain Badiou dan Masa Depan Marxisme, Resist Book, Yogyakarta.

Undang-undang Nomor 13 tahun 2003 tentang Ketenagakerjaan

Utama, L. T., 2013, Seksualitas rasa rainbow cake: memahamai keberagaman orientasi seksual manusia, Perkumpulan Keluarga Berencana Indonesia, Yogyakarta. 